\title{
The superior re-sprouting performance of exotic grass species under different environmental conditions: the study case of Paspalum atratum (Swallen) and Urochloa brizantha (Hochst. ex A. Rich. - Stapf.)
}

\author{
Giovanna M. C. L. Caramaschi · Eduardo R. M. Barbosa • \\ Dulce A. da Silva • Violeta B. Braga · Fabian Borghetti
}

Received: 16 October 2015/Accepted: 13 February 2016/Published online: 12 March 2016

(C) Brazilian Society of Plant Physiology 2016

\begin{abstract}
The invasive success of exotic grass species has been linked to a better physiological performance under a variety of environmental conditions. Several studies showed that disturbances such as fire and herbivory might favor invasions by exotic grasses in detrimental of native species. However, studies comparing how native and exotic grasses respond to variation in environmental resources under natural conditions after a disturbance are scarce. A clear understanding on how disturbances and environmental resources influence plant populations' resistance and resilience is important, and might contribute for management actions to control invasive processes in natural ecosystems. The aim of this study was to investigate how variations in light, nutrient and
\end{abstract}

G. M. C. L. Caramaschi - E. R. M. Barbosa •

F. Borghetti $(\bowtie)$

Departamento de Botânica, Universidade de Brasília,

Brasília, Distrito Federal, Brazil

e-mail: fborghet@unb.br

\section{E. R. M. Barbosa}

Resource Ecology Group, Wageningen University,

Wageningen, The Netherlands

D. A. da Silva

Embrapa Recursos Genéticos e Biotecnologia-Cenargen,

Brasília, Distrito Federal, Brazil

\section{B. Braga}

Universidade Paulista-UNIP, Brasília, Distrito Federal, Brazil water availability influence the regrowth of native and exotic grasses after a simulated disturbance (defoliation). Two $\mathrm{C}_{4}$ grass species with similar morphological and physiological characteristics were selected: the native Paspalum atratum and the African exotic Urochloa brizantha. The study was set up in a Cerrado sensu stricto area that was cleared for the experiment. Biomass production was monitored at regular intervals, and absolute growth rates for both grasses were calculated. Although irrigation did not promote further growth for both grasses, $U$. brizantha benefited more from fertilization and shade than $P$. atratum, sustaining higher growth rates until the end of the rainy season. We show that under natural conditions the exotic grass presented a higher regrowth ability than the native grass species, suggesting a stronger resilience to the variation in resource availability. Thus, natural disturbances might further stimulate the invasion and dominance of this exotic grass.

Keywords Biological invasions - Tropical savannas $\cdot$ Cerrado $\cdot$ Water $\cdot$ Nutrients $\cdot$ Defoliation

\section{Introduction}

Biological invasions affect all ecosystems on earth (Richardson 2011). It is estimated that more than one million square kilometers of the humid and sub-humid tropics have been converted to grasslands dominated 
by African $\mathrm{C}_{4}$ grasses (Williams and Baruch 2000). This conversion is still increasing due to persistent forest clearing and pasture creation and subsequent spread of these grasses into natural areas. Exotic grasses frequently escape from planted, pasture areas, becoming invaders of native vegetation, aided in part by the opening of native communities by fire and deforestation (Williams and Baruch 2000). Invasive plants may affect floristic composition and ecosystem functioning (Hejda et al. 2009) by promoting modifications of biotic and abiotic factors, changing ecological relations, such as seed dispersal and pollination interactions (Pyšek et al. 2012), leading to direct impacts in the native flora (Vilà et al. 2011; Pyšek et al. 2012). Furthermore, biological invasions are recognized as one of the main causes of biodiversity declination, which translates into reduced ecosystem services worldwide (Pyšek and Rihardson 2010).

The relative performance between native and exotic species and the consequent environment susceptibility to invasions may be related to resource availability. Communities subjected to pronounced fluctuation in their resources, either due to changes on the influx from external sources or changes in the activity of the resident organisms, will have a higher susceptibility to invasion (Grime 2001). In areas with high availability of resources, some exotic plants may present a better growth performance than the native species (Daehler 2003). Moreover, studies have also shown that some exotic plants are more efficient in areas with limited resource availability (Funk and Vitousek 2007). Exotic species usually present important functional traits for their successful establishment, such as low biomass production costs, high seed production, high growth rate, fast reproductive cycles, high tolerance to disturbance (e.g. fast resprout after fires) and high phenotypic plasticity (Daehler 2003; Foxcroft et al. 2010; Aires et al. 2014; Tooth and Leishman 2014). These traits might give to exotic grasses adaptive benefits in the gain and use of resources compared to native species, contributing to the invasion success (Rejmánek 1996; Vilà and Weiner 2004; Davidson et al. 2011; Funk 2013).

The frequency of disturbances may also contribute to exotic species invasions (Davis et al. 2000, Foxcroft et al. 2010; Masocha et al. 2011). Disturbance alter the supply of several resources, either increasing it, as for nutrients and light, or reducing it, in the case of superficial soil organic matter.
Tropical savannas are characterized by a mosaic distribution of trees and grasses, being strongly influenced by resource availability (e.g. water, nutrients, light), and by the frequency and intensity of disturbances (e.g. fire and herbivory) (Scholes and Archer 1997; Higgins et al. 2000, Sankaran et al. 2004). For instance, the Brazilian savanna (Cerrado) is an ecosystem with a high frequency of fires, every 2 or 3 years (Hoffmann et al. 2002). The Cerrado savanna is dominated by $\mathrm{C}_{4}$ grass species, and is under heavy invasion pressure from African grass species, mostly by Melinis minutiflora, Hyparrhenia rufa, Megathyrsus maximus, Urochloa spp. (brachiaria grass species) and Andropogon gayanus (Klink and Joly 1989; Pivello et al. 1999a, b; Hoffmann et al. 2004; Matos and Pivello 2009; Horowitz et al. 2013).

The competitive advantages of exotic species are specially important during the early stages of the invasive process, in particular during the seed germination and seedling establishment (Corbin and D'Antonio 2004; Mangla et al. 2011, Skálová et al. 2012). However, once new individuals successfully establish in the field, the competition for space and resources between exotic and native plants will be crucial for the maintenance of native populations, or the advance of exotic species (Corbin and D'Antonio 2004). In particular, the resilience of a given population will depend greatly on its ability to tolerate and regrow after disturbance, and on the use of resources under a variety of environmental conditions. In this context, studies on the regrowth capability of native and exotic grasses after disturbance are scarce, particularly in Neotropical savannas (Baruch and Jackson 2005). Due to the strong effect of exotic grasses invasions in reducing biodiversity in savannas (Pyšek and Rihardson 2010), this study seek to contribute to a better understanding about the resilience capability of native and exotic grass populations in the Cerrado vegetation. Thus, the aim of this study was to test how variations in water, nutrients, and light availability influence the biomass production and regrowth of a native (Paspalum atratum Swallen) and an exotic grass (U. brizantha) species after a simulated disturbance.

\section{Materials and methods}

\subsection{Experimental area}

The experiment was set in the University of Brasilia campus $\left(15^{\circ} 46^{\prime} 12^{\prime \prime} \mathrm{S} ; 47^{\circ} 52^{\prime} 07^{\prime \prime} \mathrm{W}\right)$, Brasilia, Federal 
District, Brazil. The field site was at an elevation of approximately $1040 \mathrm{~m}$. In the region the climate is classified as Aw in Köppen-Geiger (Peel et al. 2007), with a pronounced dry season from May to September, which the mean minimum and maximum temperatures are 14 and $26{ }^{\circ} \mathrm{C}$, respectively. During the rainy season, the mean minimum and maximum temperatures are 18 and $30{ }^{\circ} \mathrm{C}$, respectively (Lenza and Klink 2006), with a mean annual precipitation (MAP) of about $1500 \mathrm{~mm}$ (Geiger et al. 2011). The soil of the experimental site is classified as Red Latossoil, which is typically nutrient-poor acid soils with high levels of aluminum $(\mathrm{Al})$ and iron $(\mathrm{Fe})$, and poor in phosphorus $(\mathrm{P})$ and calcium $(\mathrm{Ca})$. Soil analysis of the field site revealed a clay content around $60 \%$ and a sand content around $16 \%$ (see Sect. 3).

The selected field site was a fenced area of approximately $1530 \mathrm{~m}^{2}$, covered by a vegetation typical of a Cerrado sensu stricto. Fifteen months before the beginning of the experiment, the vegetation was removed and the area ploughed to homogenize the soil with the objective of giving to the treatments similar start conditions. Due the proximity of the experimental blocks (all blocks were set up within this area) and due to the overall homogenization of the soil in the experimental area prior to the start of the experiment, we assumed a similarity on the soil characteristics in all blocks and plots.

\subsection{Grass species and planting procedures}

To compare the performance between an exotic and a native grass, we selected the perennial $\mathrm{C}_{4}$ African grass $U$. brizantha (Hochst. ex A. Rich.) Stapf., a species which occurs from Central-West to South territories in the African continent. U. brizantha have high biomass productivity when growing under full sun and under moderate levels of shade (Andrade et al. 2004). Due to its high productivity, this grass was introduced in Brazil for pasture, but rapidly became an invader species in native ecosystems and in degraded areas (Klink 1996; Pivello et al. 1999a). Currently, $U$. brizantha can be found distributed over large parts of the Brazilian territory, spread over virtually every fragment of the Cerrado biome (Pivello et al. 1999a, b). The native species selected is also a perennial $\mathrm{C}_{4}$ grass, $P$. atratum Swallen, a species of large distribution, occurring naturally in the Brazilian biomes Cerrado, Amazônia and Caatinga (Maciel et al.
2009). Similar to the exotic $U$. brizantha, this native grass has a tussock-shape growth, fast growth rate, high productivity and good tolerance to low-fertility soils, such characteristics that has positioned this species as a viable alternative for planted pastures in Brazil, Argentina, Thailand and Filipinas (Valentim et al. 2000; Oliveira 2004). U. brizantha individuals was surveyed in areas with different types of soils (clay, sandy or rocky soils), under wet or drier environmental conditions and also in river banks.

In order to establish a uniform grass cover, $50 \mathrm{~g}$ of seeds of $P$. atratum and $U$. brizantha were sowed separately in $4 \mathrm{~m}^{2}$ plots and cultivated under daily irrigation during 15 months (November 2009-February 2011) to assure grass establishment. Whenever needed new sowing was done during this period to develop a homogeneous grass cover in all plots. After 15 months of growth (February 2011), the grasses were cut about $2 \mathrm{~cm}$ aboveground to simulate a biomass lost due to a disturbance. In the following months the plots received freely the water provided by rainfall events. The plots did not received extra water supply during the following dry season (March-September 2011).

\subsection{Experimental and treatments design}

The experimental area was divided in five replicate blocks, each block being divided in three parcels of $54 \mathrm{~m}^{2}$ each. One parcel was covered with a shading net and a transparent plastic which reduced the natural light by around $80 \%$ and intercepted natural rainfall. The second parcel was covered only with a transparent plastic, thus intercepting only natural rainfall. The third parcel was not covered, thus subjected to both natural sunlight and rainfall. Each parcel was further divided in six plots of $4 \mathrm{~m}^{2}$ each, separated from each other by a gap of $2 \mathrm{~m}$, a total of 90 plots. In these plots the grasses were sowed as already described.

The native (G1) and exotic (G2) grasses were independently subjected to incomplete crossed treatment, resulting in six treatments combinations: (1) fertilized (N1) not fertilized (N0); (2) shaded (L1) not shaded (L0); (3) irrigated (W1) not irrigated (W0). The treatments were replicated five times (five blocks).

In the irrigation treatment (W1) a drip irrigation system was installed and set to irrigate the grasses twice a day. The volume of water used in this treatment was $37.5 \mathrm{~L} \mathrm{~m}^{-2}(37.5 \mathrm{~mm})$ per week, 
totalizing an equivalent of $1050 \mathrm{~mm}$ of rain uniformly distributed from October to April. In the treatment with no irrigation (W0) the plots received only the water provided by rainfall events during the experimental period (Fig. 1). In the fertilization treatment (N1), Osmocote ${ }^{\circledR}$ inorganic fertilizer (15:9:12) was applied every month from April to July 2011 (26.7 g/ $\mathrm{m}^{2}$ per application). This quantity was determined based on the addition of $4 \mathrm{~g}$ of nitrogen per square meter (Tilman 1987; Kraaij and Ward 2006; Tomlinson et al. 2012; Barbosa et al. 2014).

After the defoliation done in February of 2011, the regrowth of the grasses was followed during the wet season by periodically harvesting the aboveground biomass to access growth performance. The harvesting was done four times during the wet season; (1) begin of the rainy season (October 2011), (2) early middle (December 2011), (3) late middle (February 2012) and (4) at the end of rainy season (April 2012). The aboveground biomass of the grasses was collected by using pruning shears at around $2 \mathrm{~cm}$ above the ground. To avoid interference of one harvest in the next, the plots were divided into 32 sub-plots of $0.125 \mathrm{~m}^{2}$, and the harvesting was done randomly in different sub-plots, avoiding sub-plots previously selected. For dry biomass estimates the samples were oven-dried at $70{ }^{\circ} \mathrm{C}$ for $48 \mathrm{~h}$.

After the last harvesting (April 2012), soil samples of the plots WOLONO (natural rainfall, full sun and no nutrient addition) without grass cover (bare soil), and with grass cover (from both grass species) were collected, mixed and sent for physical and chemical analysis. Leaf samples of both grasses were also sent for macro and micro-nutrients analysis.

\subsection{Data analysis}

Based on the total shoot biomass measured at each interval the absolute growth rate (AGR) was calculated. The AGR was calculated according to the formula below (Tomlinson et al. 2012; adapted from Hoffmann and Poorter 2002):

$\mathrm{AGR}=\frac{\mathrm{BM} 2-\mathrm{BM} 1}{60}$,

where AGR defines absolute growth rate, BM2 defines aboveground dry biomass in time 2 (T2) and $\mathrm{BM} 1=$ aboveground dry biomass in time 1 (T1).

To calculate the AGR during the rainy season (October 2011-April 2012), the growth measurements of the grasses were divided in three intervals of 2 months: Start, represented by the absolute growth rate during the months from October 2011 up to December 2011; Middle, represented by the absolute growth rate during the months from December 2011 up to February 2012; and Late, represented by the absolute growth rate between February 2012 up to April 2012.

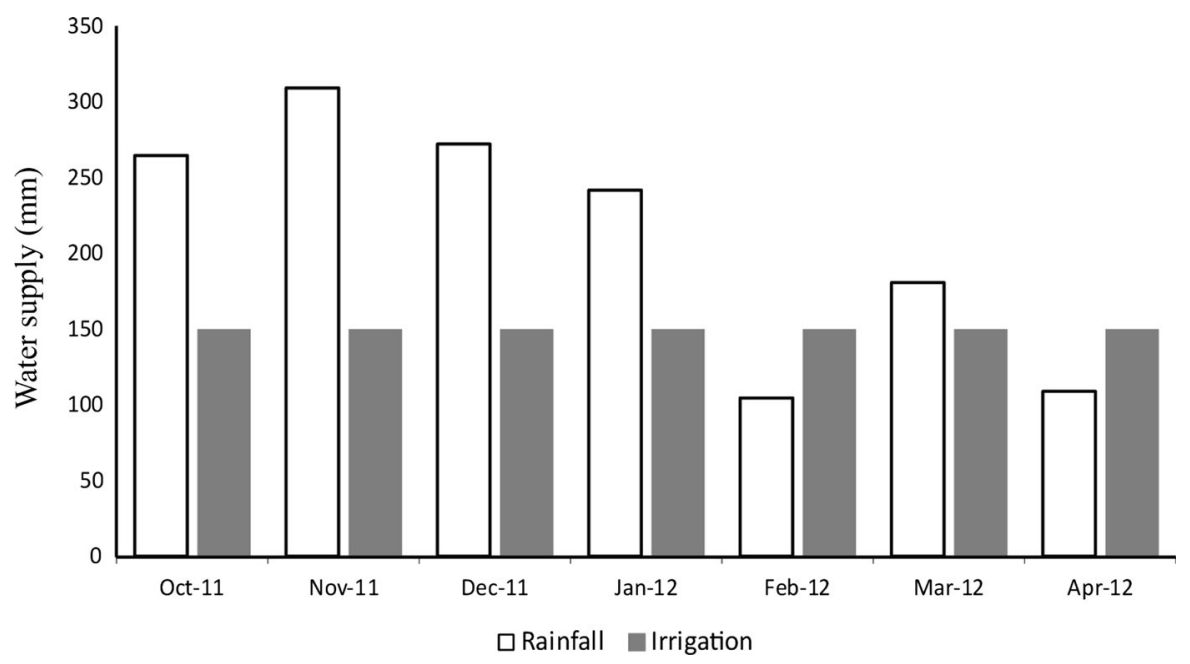

Fig. 1 The monthly water supply on the plots during the experimental period. In the irrigation treatment (W1) a drip irrigation system was installed, set to irrigate the grasses twice a day. The volume of water used in this treatment was $37.5 \mathrm{~mm}$ per week, totalizing an equivalent of $1050 \mathrm{~mm}$ of rain uniformly distributed from October to April. In the no irrigation treatment (W0) the plots were received only the water prevenient from the rainfall events during the experimental period 
The data were analyzed using linear mixed models (GLMMs). The dependent variable was the AGR, and the independent variables were: species (G1 and G2), irrigation (W0 and $\mathrm{W} 1$ ), light (L0 and L1), nutrients (N0 and N1) and time (T1, T2, and T3). To account for the nested sampling design, plots within block were included as random variables. The statistical package used in the analysis was the IBM SPSS Statistics, 21.0 (IBM Corp. IBM SPSS Statistics for Windows, Version 22.0 Armonk, NY). Due to logistic constrains, it was not possible to have a full factorial design. Since there was not the L1W0 (shade and natural rainfall) treatment, the variables were analyzed independently, i.e. treatments with and without shading or treatments with and without irrigation.

\section{Results}

\subsection{The growth of the grasses during the dry} and rainy seasons

The present work followed the aboveground regrowth after defoliation of native and exotic grasses over 14 months under field conditions. During the dry season (May-October 2011), the aboveground biomass and growth rate was low and similar for both grasses (data not shown). However, during the rainy season both grasses showed a pronounced and similar increase in their biomass. Although no statistical differences were detected, the exotic grass always presented a higher biomass production than the native one (Fig. 2). The statistical analysis showed a high variation on the growth of grasses during the rainy season $\left(p<0.0001, F_{162.959}=8.580\right.$, Table 1$)$. In the beginning of the rainy season (October-December), native and exotic grasses showed a similar increase in biomass allocation, followed by a peak of biomass production between December and February. However, only the exotic $U$. brizantha sustained high growth rates in the end of the rainy season (FebruaryApril) (Fig. 2).

\subsection{Irrigation and fertilization effects on the growth rates of the grasses}

Our results show that irrigation and fertilization, alone, have no influence in the AGR of both grasses
( $p=0.230$ and $p=0.866$, respectively, Table 1$)$. However, a trend to a significant difference between exotic and native AGR was observed $(p=0.086)$. Moreover, the interaction between the factors water and time $(p=0.058)$, species and time $(p=0.082)$ and between water, nutrient and time $(p=0.095)$ also showed values close to the borderline of statistical significance (Table 1).

In plots without fertilization (N0), the absolute growth rates of native and exotic grasses were similar (Fig. 3). In the first months of the rainy season the native grass showed higher AGR, however, in late rainy season, only the exotic grass maintained a high AGR, while the native grass species showed a decreased in the absolute growth rate (Fig. 3). Under fertilization treatment this trend was observed in the first months. However, under fertilization, the AGR presented by the exotic grass was always higher than that of the native grass. Moreover, both species showed a decline in the AGR at the end of the rainy season (Fig. 3). In contrast, the native grass did not show a positive response to fertilization; on the contrary, negatives values of AGR were detected at the end of the rainy season (Fig. 3).

\subsection{Effect of fertilization on the growth rates of the grasses under shade}

Due to logistic constraints (impossibility to set up a shaded environment under natural rainfall), it was not possible to analyze the influence of irrigation and the interaction between irrigation and shade. However, it was possible to evaluate how shade influences the response of the grasses species to fertilization. Shade $(p=0.125)$ and fertilization $(p=0.592)$ alone did not influence the AGR values of both grasses (Table 2). Moreover, no significant differences were found for the growth rates of native and exotic grasses growing under shade $(p=0.147)$ (Table 2$)$. However, shade affected the AGR over time $(p<0.0001$, $F_{162.898}=15.166$ ), leading to significant variations in the AGR during the growing season (Table 2). Furthermore, significant results were detected in the interactions among fertilization and time $(p=0.014$, $\left.F_{162.898}=4.398\right), \quad$ species and time $(p=0.011$, $\left.F_{162.898}=4.685\right)$ and in the interaction between shade, species and time $\left(p=0.018, \quad F_{162.898}=\right.$ 4.124) (Table 2). Our analyses suggest that the effects 
Fig. 2 The average aboveground biomass produced during the rainy season (October 2011-April 2012) of the grass species $P$. atratum and $U$. brizantha. Time 1 (October 2011December 2011), time 2 (December 2011-February 2012) and Time 3 (February 2012-April 2012). Error Bars represents $95 \%$ confident intervals. $n s$ no significant; $* p>0.05$; $* * * p>0.0001$

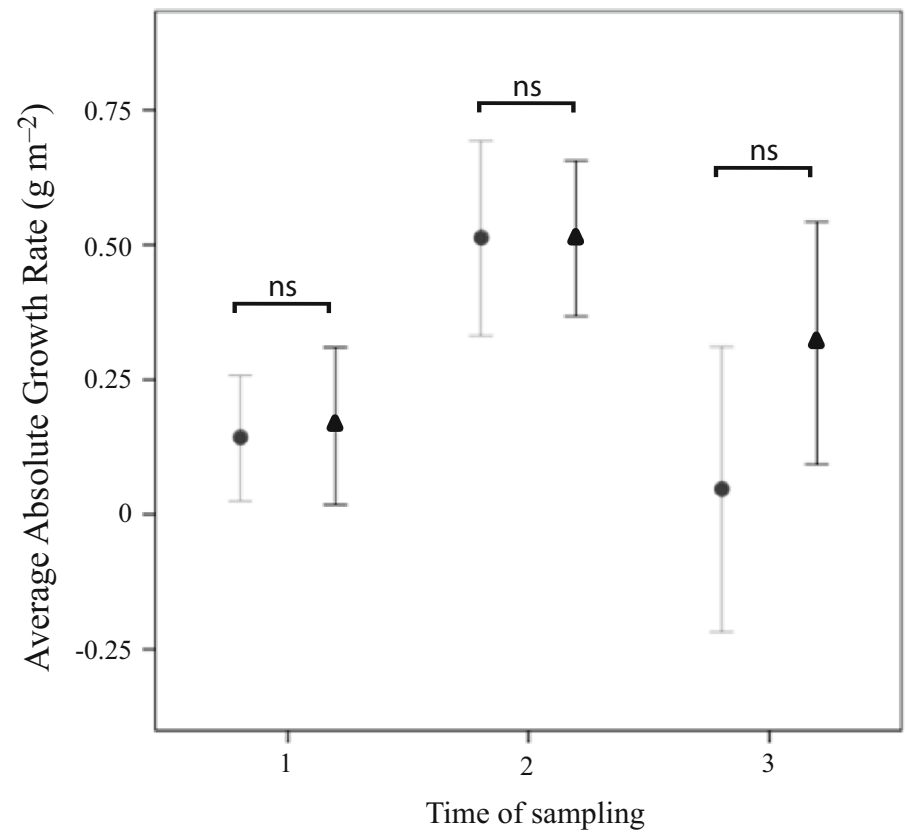

Paspalum atratum

Urochloa bizantha
Table 1 Results from the general linear mix models analysis testing the effects of irrigation, fertilization, time and species on the absolute growth rate (AGR) of grass species $P$. atratum and $U$. brizantha

\begin{tabular}{lcrc}
\hline & Degrees of freedom & $F$-value & $p$ value \\
\hline Intercept & 5.321 & 30.423 & 0.002 \\
Irrigation (W) & 163.374 & 1.451 & 0.230 \\
Fertilization (N) & 163.252 & 0.028 & 0.866 \\
Species (S) & 163.374 & 2.980 & 0.086 \\
Time $(\mathrm{T})$ & 162.959 & 8.580 & 0.000 \\
$\mathrm{~W} \times \mathrm{N}$ & 163.252 & 0.898 & 0.345 \\
$\mathrm{~W} \times \mathrm{S}$ & 163.374 & 1.081 & 0.300 \\
$\mathrm{~W} \times \mathrm{T}$ & 162.959 & 2.895 & 0.058 \\
$\mathrm{~N} \times \mathrm{S}$ & 163.252 & 1.073 & 0.302 \\
$\mathrm{~N} \times \mathrm{T}$ & 162.959 & 2.059 & 0.131 \\
$\mathrm{~S} \times \mathrm{T}$ & 162.959 & 2.545 & 0.082 \\
$\mathrm{~W} \times \mathrm{N} \times \mathrm{S}$ & 163.252 & 0.227 & 0.634 \\
$\mathrm{~W} \times \mathrm{N} \times \mathrm{T}$ & 162.959 & 2.385 & 0.095 \\
$\mathrm{~W} \times \mathrm{S} \times \mathrm{T}$ & 162.959 & 0.941 & 0.392 \\
$\mathrm{~N} \times \mathrm{S} \times \mathrm{T}$ & 162.959 & 0.189 & 0.828 \\
$\mathrm{~W} \times \mathrm{N} \times \mathrm{S} \times \mathrm{T}$ & 162.959 & 0.351 & 0.705 \\
\hline $\mathrm{T}$ & &
\end{tabular}

The block and plot was used as random variables in the model

of the treatments on the AGR of the grasses become more evident throughout the growing period (Fig. 4).

\subsection{Soil physical and chemical analysis} of the experimental area

The soil analysis of the experimental area revealed the presence of an acid sandy-loam soil, $\mathrm{pH}$ between 4.5 and 4.8 and a relatively high concentration of potassium, sulfur, iron and manganese (Table 3). The soil of the area is classified as Red Latossoil, the most common type of soil in the Cerrado biome (Reatto et al. 2008). Soil samples from plots covered by $P$. atratum and $U$. Brizantha showed similarities in the quantities of most mineral elements, however, there were differences in the amounts of sulfur and manganese, which were lower in plots covered by $P$. atratum (Table 3). In contrast, plots with native grass presented a higher amount of organic matter. The base saturation (V) and cation exchange capacity (CEC) was low for both grasses, and similar to bare soil (Table 3). The most evident differences between bare soil and soils covered with grasses were the lower quantities of potassium and iron elements in the first case (Table 3). Furthermore, the grasses did not interfere in other relevant parameters such as soil $\mathrm{pH}$ and fertility, and had a minor effect on the soil organic matter. 
Fig. 3 Average absolute growth rate (AGR) of the grass species $P$. atratum ang $U$. brizantha during the rainy season (from October 2011 up to April 2012). Time 1 (October 2011December 2011), time 2 (December 2011-February 2012) and Time 3 (February 2012-April 2012). Error bars represents $95 \%$ confident intervals. The figure represents the results showed in Table 1. ns no significant; $* p>0.05$ $* * * p>0.0001$

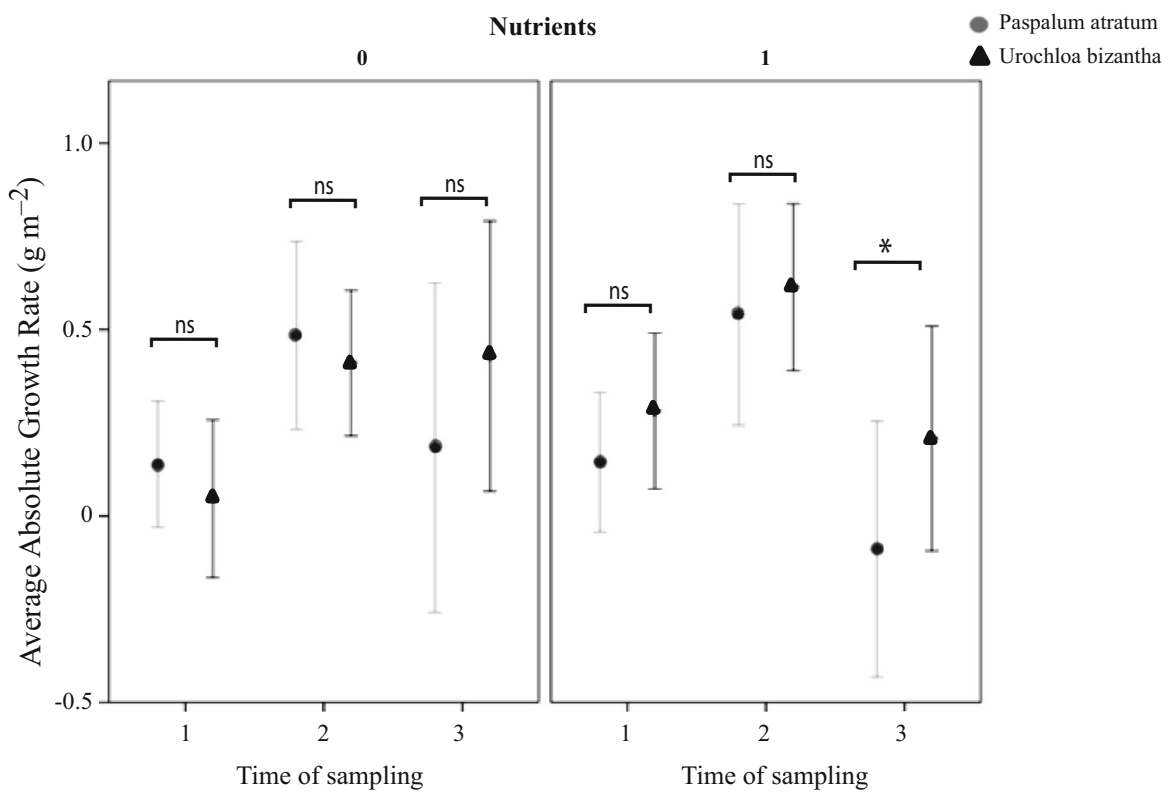

Table 2 Results from the general linear mix models analysis testing the effects of shade, fertilization, time and species on the absolute growth rate (AGR) of grass species $P$. atratum and $U$. brizantha

\begin{tabular}{lcrl}
\hline & Degrees of freedom & $F$-value & $p$ value \\
\hline Intercept & 6.052 & 21.692 & 0.003 \\
Shade (L) & 165.233 & 2.380 & 0.125 \\
Fertilization (N) & 164.600 & 0.289 & 0.592 \\
Species (S) & 165.233 & 2.125 & 0.147 \\
Time (T) & 162.898 & 15.166 & 0.000 \\
$\mathrm{~L} \times \mathrm{N}$ & 164.600 & 1.397 & 0.239 \\
$\mathrm{~L} \times \mathrm{S}$ & 165.233 & 0.003 & 0.959 \\
$\mathrm{~L} \times \mathrm{T}$ & 162.898 & 2.430 & 0.091 \\
$\mathrm{~N} \times \mathrm{S}$ & 164.600 & 0.928 & 0.337 \\
$\mathrm{~N} \times \mathrm{T}$ & 162.898 & 4.398 & 0.014 \\
$\mathrm{~S} \times \mathrm{T}$ & 162.898 & 4.685 & 0.011 \\
$\mathrm{~L} \times \mathrm{N} \times \mathrm{S}$ & 164.600 & 0.207 & 0.650 \\
$\mathrm{~L} \times \mathrm{N} \times \mathrm{T}$ & 162.898 & 1.542 & 0.217 \\
$\mathrm{~L} \times \mathrm{S} \times \mathrm{T}$ & 162.898 & 4.124 & 0.018 \\
$\mathrm{~N} \times \mathrm{S} \times \mathrm{T}$ & 162.898 & 0.006 & 0.994 \\
$\mathrm{~L} \times \mathrm{N} \times \mathrm{S} \times \mathrm{T}$ & 162.898 & 0.368 & 0.693 \\
\hline $\mathrm{T}$ & &
\end{tabular}

The block and plot was used as random variables in the model

\subsection{Leaf nutrient analysis of the grasses}

Nutrients analysis of leaves of $U$. brizantha and $P$. atratum showed similar contents of phosphorus, sulfur, boron, zinc and manganese (Table 4). A higher concentration of potassium, magnesium and iron was found in the leaves of $P$. atratum, and a higher concentration of nitrogen and calcium was found in the leaves of $U$. brizantha (Table 4).

\section{Discussion}

4.1 The growth of the grasses during the dry and rainy seasons

Studies comparing the grow of grasses under diverse experimental conditions have showed that exotic grasses usually have higher rates of growth when compared to native species (D'Antonio and Vitousek 1992; Pivello et al. 1999a; Rossiter et al. 2003; Han et al. 2012). Moreover, previous studies suggested that the high growth rates are possibly related to the fact that invasive species tend to have higher photosynthetic efficiency and better performance in the acquisition of resources as water and nutrients, when compared to native grasses (D'Antonio and Vitousek 1992; Foxcroft et al. 2010; Firn et al. 2012). The statistical analysis showed a high variation on the growth of grasses during the rainy season $(p<0.0001$, $F_{162.959}=8.580$, Table 1$)$. When dividing the growing season in periods of 2 months, the results show that 
Fig. 4 Average absolute growth rate (AGR) of the grass species $P$. atratum and $U$. brizantha growing under different nutrient levels $(N O$ no nutrient addition and $N 1$ nutrient additions) during the rainy season (from October 2011 up to April 2012). Time 1 (October 2011-December 2011), time 2 (December 2011-

February 2012) and Time 3

(February 2012-April

2012). Error bars represents $95 \%$ confident intervals. The figures represent the results showed in Table 2. $n s$ no significant;

$* p>0.05 ; * * * p>0.0001$

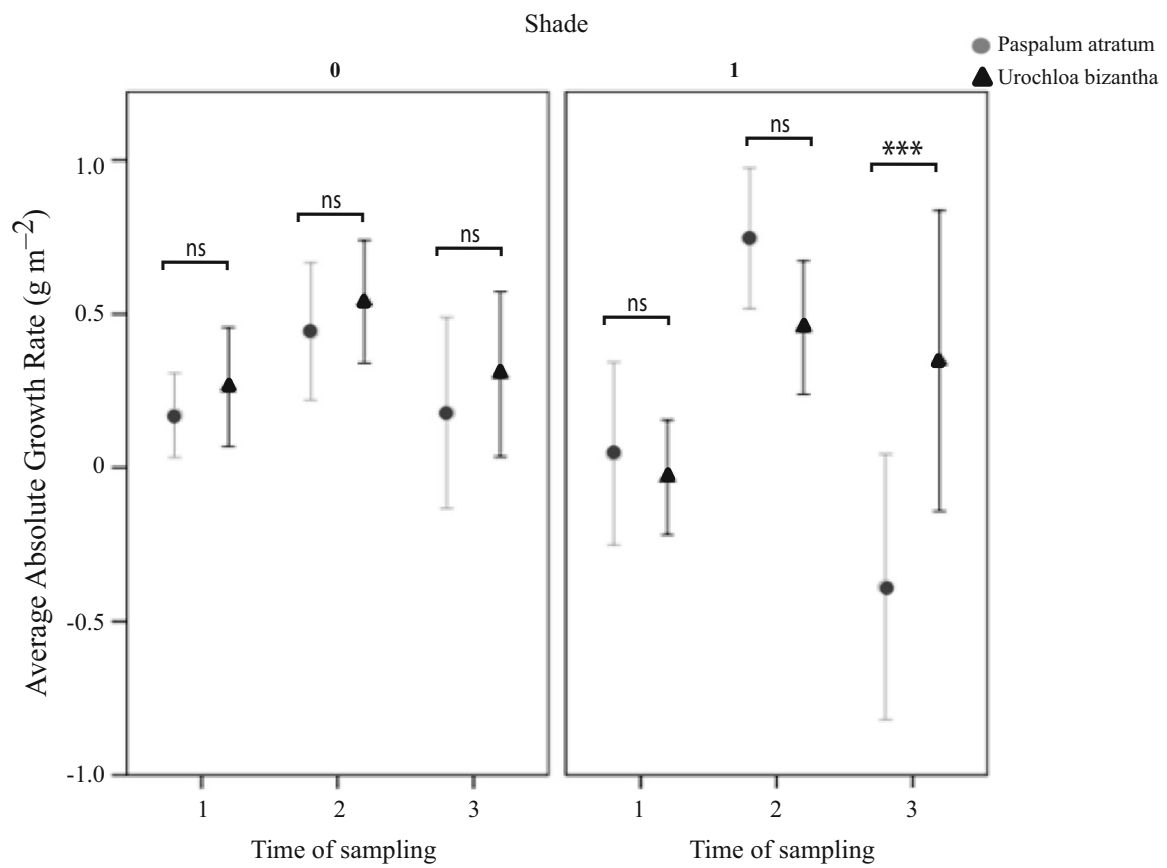

native and exotic grasses had the peak of biomass production between December 2011 and February 2012. However, only the exotic $U$. brizantha sustained high growth rates in the end of the rainy season
(February-April) (Fig. 2). The higher performance of the exotic grass after defoliation denotes its great ability to recover rapidly after disturbance, increasing their potential to spread over disturbed sites.
Table 3 Physical and chemical analysis of soil samples from the experimental area collected after the end of the experiments: bare soilwithout vegetation, soil covered with $P$. atratum and soil covered with $U$. brizantha

\begin{tabular}{llll}
\hline & Bare soil & P. atratum & U. brizantha \\
\hline Silt:clay:sand (\%) & $16: 23: 61$ & $17: 30: 53$ & $16: 23: 61$ \\
Soil classification & Clay loam-sandy & Clay loam-sandy & Clay loam-sandy \\
Water pH & 4.7 & 4.5 & 4.8 \\
Organic material $\left(\mathrm{dag} \mathrm{kg}^{-1}\right)$ & 2.4 & 3.2 & 2.5 \\
$\mathrm{P}\left(\mathrm{mg} \mathrm{dm}^{-3}\right)$ & 0.5 & 0.5 & 0.6 \\
$\mathrm{~K}\left(\mathrm{mg} \mathrm{dm}^{-3}\right)$ & 22 & 32.6 & 37.2 \\
$\mathrm{~S}\left(\mathrm{mg} \mathrm{dm}^{-3}\right)$ & 7.5 & 2.6 & 6.8 \\
$\mathrm{Ca}\left(\mathrm{cmolc} \mathrm{dm}^{-3}\right)$ & 0.2 & 0.4 & 0.3 \\
$\mathrm{Mg}\left(\mathrm{cmolc} \mathrm{dm}^{-3}\right)$ & 0.1 & 0.1 & 0.1 \\
$\mathrm{Al}\left(\mathrm{cmolc} \mathrm{dm}^{-3}\right)$ & 0.2 & 0.3 & 0.2 \\
$\mathrm{CTC} \mathrm{total}\left(\mathrm{cmolc} \mathrm{dm}^{-3}\right)$ & 4.0 & 5.7 & 3.8 \\
$\mathrm{~V}(\%)$ & 10 & 11 & 13 \\
$\mathrm{~m}(\%)$ & 33 & 33 & 29 \\
B $\left(\mathrm{mg} \mathrm{dm}^{-3}\right)$ & 0.1 & 0.1 & 0.1 \\
$\mathrm{Zn}\left(\mathrm{mg} \mathrm{dm}^{-3}\right)$ & 1.5 & 0.9 & 1.6 \\
$\mathrm{Fe}\left(\mathrm{mg} \mathrm{dm}^{-3}\right)$ & 55.5 & 83 & 93.2 \\
$\mathrm{Mn}\left(\mathrm{mg} \mathrm{dm}^{-3}\right)$ & 41.7 & 16.9 & 65 \\
$\mathrm{Cu}\left(\mathrm{mg} \mathrm{dm}^{-3}\right)$ & 1.1 & 1.1 & 1.3 \\
\hline
\end{tabular}


Table 4 Leaf nutrients analysis of $P$. atratum and $U$. brizantha

\begin{tabular}{lll}
\hline & P. atratum & U. brizantha \\
\hline $\mathrm{N}\left(\mathrm{g} \mathrm{kg}^{-1}\right)$ & 0.7 & 0.9 \\
$\mathrm{P}\left(\mathrm{g} \mathrm{kg}^{-1}\right)$ & 0.6 & 0.5 \\
$\mathrm{~K}\left(\mathrm{~g} \mathrm{~kg}^{-1}\right)$ & 7.1 & 4.7 \\
$\mathrm{Ca}\left(\mathrm{g} \mathrm{kg}^{-1}\right)$ & 7.9 & 10 \\
$\mathrm{Mg}\left(\mathrm{g} \mathrm{kg}^{-1}\right)$ & 4.7 & 1.8 \\
$\mathrm{~S}\left(\mathrm{~g} \mathrm{~kg}^{-1}\right)$ & 0.6 & 0.8 \\
$\mathrm{~B}\left(\mathrm{mg} \mathrm{kg}^{-1}\right)$ & 6 & 5 \\
$\mathrm{Zn}\left(\mathrm{mg} \mathrm{kg}^{-1}\right)$ & 23 & 27 \\
$\mathrm{Fe}\left(\mathrm{mg} \mathrm{kg}^{-1}\right)$ & 647 & 119 \\
$\mathrm{Mn}\left(\mathrm{mg} \mathrm{kg}^{-1}\right)$ & 166 & 164 \\
$\mathrm{Cu}\left(\mathrm{mg} \mathrm{kg}^{-1}\right)$ & 12 & 6
\end{tabular}

The experiments were conducted in an experimental area located at the University of Brasilia, between May 2011 and April 2012. Leaf certificate of analysis: field agricultural and environmental analysis

\subsection{Irrigation and fertilization effects} on the growth rates of the grasses

Due to the irregularity in the rainfall distribution during the rainy season in the Cerrado biome (Assad and Evangelista 1994; Baruch and Jackson 2005), the expectation was that the regular irrigation regime would increase the (re)growth of grasses compared to treatments subject to natural rainfall. However, no significant differences were detected in the growth rates for both species when compared to the individuals growing under regular (W1) or irregular (W0) water regimes (Fig. 1). These results suggest that the regrowth of grasses established at least 15 months is not affected by the dry spells observed during the rainy season, as both native and exotic grasses showed similar performance in their biomass allocation to aboveground in both water treatments (Table 1, W interaction $\times \mathrm{S} \times \mathrm{T}, \quad p=0.392)$. Furthermore, although it is reported that irrigation significantly promoted the sprouting of exotic grasses (e.g. $M$. minutiflora and H. rufa, see Baruch and Jackson 2005) in comparison to native grass species, it is suggested that the water use efficiency of the plants is not among the factors that explain the differences in performance of exotic native species (Daehler 2003).

In plots without fertilization (N0), the absolute growth rates of native and exotic grasses were similar
(Fig. 3). Under fertilization treatment, the AGR presented by the exotic grass was always higher than that of the native grass. Moreover, both species showed a decline in the AGR at the end of the rainy season (Fig. 3). The ability of invasive species to rapidly resprout or even present a high seedling growth has been linked to their greater ability to mobilize resources, especially nitrogen, when compared to native species, which represents a strong competitive advantage for the exotic plants (Lambers and Poorter 1992). In particular, Urochloa species are characterized by their ability to survive in different soils conditions, including acidic and nutrient-poor soils (Andrade et al. 2004) as is the case of the soils of savanna formations in the Cerrado (Reatto et al. 2008). In contrast, the native grass did not show a positive response to fertilization; on the contrary, they showed negatives values of AGR at the end of the rainy season (Fig. 3). These results indicate that the AGR of the native grass may decrease during the growing season. Despite the low availability of several nutrients, the Cerrado soils are eventually subjected to temporary inputs of nutrients due to the mineralization of burned plant material during a fire (Nardoto et al. 2006). Studies show that these nutrient inputs are more beneficial to exotic than native plant species (Huenneke et al. 1990; Kolb et al. 2002; Vallano et al. 2012), supporting the hypothesis that high frequency of disturbance is a major determinant of exotic species success in disturbed areas (Davis et al. 2000; Masocha et al. 2011). Our results corroborate the idea that exotic grasses have a higher capacity to use nutrients more rapidly and efficiently when compared to native grass, increasing the chances of establishment after a disturbance. This helps to explain the expansion of alien species in several areas of the Cerrado biome.

It is also important to mention that the exotic grass presented a higher performance of growth compared to $P$. atratum, a native species which also presents a high productivity and performance under different conditions (Valentim et al. 2000; Oliveira 2004). This tiny difference in growth pattern can make a huge difference over time, and exotic grasses may become a major threat to native grass populations of the Cerrado, especially with the ongoing increase of human activities such as soil fertilization and increased fire frequency. These observations also contribute to understand why exotic grasses benefit more than native grasses from soil fertilization in 
pasture areas and even in programs of reforestation with native grasses and tree seedlings (Martins et al. 2004).

\subsection{Effect of fertilization on the growth rates of the grasses under shade}

The native and exotic grasses growing under natural light conditions showed no significant differences in their absolute growth rates, although throughout this period the AGR values of the exotic grass was always higher than those calculated for the native grass (Fig. 4). Under shade, the native $P$. atratum showed higher growth rates in the first months, however, this species showed a sudden drop in the AGR in the end of the rainy season (Fig. 4). In contrast, $U$. brizantha sustained a high growth rates until the late rainy season, confirming its ability to maintain a high biomass production until the end of the growing period (Fig. 4). Urochloa species have a good capacity to adapt to different environmental conditions, including shaded environments. For instance, Dias-Filho (2000) observed that $U$. brizantha and $U$. humidicola reduced their growth rates under shade. However, our study also shows that even the individuals subjected to shade showed increase in their biomass production. Other exotic grasses, such as M. minutiflora, M. maximus and Schizachyrium condensatum also showed a great capacity to tolerate low light conditions (D'Antonio et al. 2001; Ammondt et al. 2013).

Our results demonstrate that the exotic grass $U$. brizantha presented an overall better performance in the absolute growth rates than the native grass $P$. atratum under full light conditions, also keeping a higher AGR under shade in the late rainy season. These characteristics suggest that light conditions may not limit the spread of $U$. brizantha to shaded environments of the Cerrado.

\subsection{Soil physical and chemical analysis}

of the experimental area

Soil samples from plots covered by $P$. atratum and $U$. brizantha showed similarities in the quantities of most mineral elements (Table 3). In contrast, plots with native grass presented a higher amount of organic matter. Furthermore, we found no evidence that different grass species have dissimilar interferences in other relevant soil parameters, such as, soil $\mathrm{pH}$ and fertility, and had a minor effect on the soil organic matter.

In general, macro and micronutrients are more available during the rainy than during the dry season, due the fact that water is required for nutrient mobilization from the soil to the plants. Moreover, the microbial activity is also higher during the warm rainy season, increasing the nutrients availability in the soils (e.g. Pivello et al. 2010). Thus, in the beginning of the rainy season, the soils nutrients become more available and are rapidly overtaken by grasses to build their structural components (biomass), reducing its availability in the soils overtime. As invasive grass species showed efficiency in resource-limited habitats (Funk and Vitousek 2007), apparently these species demonstrate a lower nutritional requirement compared to native grasses species.

\subsection{Leaf nutrient analysis of the grasses}

The results obtained from the leaf nutrients analysis suggested that the native grass have higher absorption rates of potassium, magnesium, iron and copper in comparison to $U$. brizantha. In contrast, the exotic grass seems to have higher absorption rates of calcium, considering the reduced amount of this element in plots cultivated with $U$. brizantha. Despite the differences in the soil concentration of sulfur, the differences in the amounts of leaf elements between the two species were minor, suggesting similarities on the leaf nutrient-use strategies between these grasses (Table 4). Consequently, the better performance of exotic over the native grass observed here might be not related directly to differences in the mineral nutrient metabolism of them.

\subsection{Final considerations}

This study aimed to compare regrowth potential of two grasses, the native P. atratum and the exotic Urochloa brizantha after aboveground defoliation (simulating disturbances such as fire and herbivory) under different resource conditions. In general, the exotic showed higher growth rates, in particular at the end of the rainy season, and higher average biomass production compared with the native grass. Continuous water 
availability did not enhance growth of both grass species. However, the exotic grass showed a better performance when grown in fertilized plots, and kept growing when subjected to shade.

The results of this study suggest that the exotic $U$. brizantha might increase its distribution under intensification in frequency of disturbances. In agreement with previous studies (Pivello et al. 1999a; Baruch and Jackson 2005; Masocha et al. 2011), our results suggest that exotic grasses performed better under a variety of conditions associated with the increased frequency of disturbance, and changes in land use might lead to modifications in the savanna grass composition, favoring the spread of exotic grasses and displacement of the native ones. Furthermore, considering also that exotic grasses reduce survival rates of savanna tree seedlings (Hoffmann and Haridasan 2008), the shifts in the grass cover of savanna areas may also lead to substantial effects on the dynamics of the tree community, with likely consequences for ecosystem structure and function. As species of the genus Urochloa are among the most common and aggressive exotic grass species introduced in the Cerrado biome (Pivello et al. 1999b; Almeida-Neto et al. 2010; Lannes et al. 2012), the ongoing increase of these and other exotic grasses in the Brazilian savanna ecosystems will likely lead to severe changes in the plant population composition and, consequently leading to loses in biodiversity and ecological services provide by the natural plant populations of the Cerrado Biome.

Acknowledgments We wish to thank the Coordenação de Aperfeiçoamento de Pessoal de Nivel Superior (CAPES) for the grant which they have kindly conceded to the first author, as well as for their financial support (CAPES/NUFFIC process 019/10) to conduct this research. This research was also partially supported by Fundação de Apoio ao Desenvolvimento Científico e Tecnológico do Distrito Federal (FAP-DF processo 193.000.051/2012).

\section{References}

Aires SS, Sato MN, Miranda HS (2014) Seed characterization and direct sowing of native grass species as management tool. Grass Forage Sci 69:470-478

Almeida-Neto M, Prado PI, Kubota U, Bariani JM, Aguirre GH, Lewinsohn TM (2010) Invasive grasses and native Asteraceae in the Brazilian Cerrado. Plant Ecol 209:109-122

Ammondt SA, Litton CM, Ellsworth LM, Leary JK (2013) Restoration of native plant communities in a Hawaiian dry, lowland ecosystem dominated by the invasive grass $\mathrm{Me}$ gathyrsus maximus. J Appl Veg Sci 16:29-39

Andrade CMS, Valentim JF, Carneiro JC, Vaz FA (2004) The growth of tropical grasses and forage leguminosae plants under shade environments. Pesq Agropecu Bras 39:263-270

Assad ED, Evangelista BA (1994) Análise frequencial da precipitação pluviométrica. In: Assad ED (ed) Chuvas no Cerrado: análise e espacialização. Embrapa/CPAC, Brasília, pp 25-42

Barbosa ER, van Langevelde F, Tomlinson KW, Carvalheiro LG, Kirkman K, de Bie S, Prins HH (2014) Tree species from different functional groups respond differently to environmental changes during establishment. Oecologia 174:1345-1357

Baruch Z, Jackson RB (2005) Responses of tropical native and invader $\mathrm{C}_{4}$ grasses to water stress, clipping and increased atmospheric $\mathrm{CO}_{2}$ concentration. Oecologia 145:522-532

Corbin JD, D'Antonio CM (2004) Competition between native perennial and exotic annual grasses: implications for an historical invasion. Ecology 85:1273-1283

D'Antonio CM, Vitousek PM (1992) Biological invasions of alien grasses the grass/fire cycle and global change. Annu Rev Ecol Syst 23:63-87

D'Antonio CM, Hughes RF, Vitousek PM (2001) Factors influencing dynamics of two invasive $\mathrm{C}_{4}$ grasses in seasonally dry Hawaiian woodlands. Ecology 82:89-104

Daehler CC (2003) Performance comparisons of co-occurring native and alien invasive plants: implications for conservation and restoration. Annu Rev Ecol Syst 34:183-211

Davidson AM, Jennions M, Nicotra AB (2011) Do invasive species show higher phenotypic plasticity than native species and if so is it adaptive? A meta analysis. Ecol Lett 14:419-431

Davis MA, Grime JP, Thompson K (2000) Fluctuating resources in plant communities: a general theory of invisibility. J Ecol 88:528-534

Dias-Filho MB (2000) Growth and biomass alocation of the $\mathrm{C}_{4}$ grasses Brachiaria brizantha e $B$ humidicola under shade. Pesq Agropecu Bras 35:2335-2341

Firn J, Prober SM, Buckley YM (2012) Plastic traits of an exotic grass contribute to its abundance but are not always favorable. PLoS One 7(4):e35870. doi:10.1371/journal. pone. 0035870

Foxcroft LC, Richardson DM, Rejmanek M, Pysek P (2010) Alien plant invasions in tropical and sub-tropical savannas: patterns processes and prospects. Biol Invasions 12:3913-3933

Funk JL (2013) The physiology of invasive plants in low-resource environments. Conserv Physiol 1:cot026

Funk JL, Vitousek PM (2007) Resource use efficiency and plant invasion in low-resource systems. Nature 446:1079-1081

Geiger EL, Gotsch SG, Damasco G, Haridasan M, Franco AC, Hoffmannn WA (2011) Distinct roles of savanna and forest tree species in regeneration under fire suppression in a Brazilian savanna. J Veg Sci 22:312-321

Grime JP (2001) Plant strategies, vegetation processes, and ecosystem properties, 2nd edn. John Wiley and Sons Ltd, New York, 417 pp

Han Y, Buckley YM, Firn J (2012) An invasive grass shows colonization advantages over native grasses under 
conditions of low resource availability. Plant Ecol 213:1117-1130

Hejda M, Pyšek P, Jarošík V (2009) Impact of invasive plants on the species richness diversity and composition of invaded communities. J Ecol 97:393-403

Higgins SI, Bond WJ, Trollope WSW (2000) Fire resprouting and variability: a recipe for grass-tree coexistence in savanna. J Ecol 88:213-229

Hoffmann WA, Haridasan M (2008) The invasive grass, melinis minutiflora, inhibits tree regeneration in a Neotropical savanna. Austral Ecol 33:29-36

Hoffmann WA, Poorter H (2002) Avoiding bias in calculation of relative growth rate. Ann Bot 80:37-42

Hoffmann WA, Schroeder W, Jackson RB (2002) Positive feedbacks of fire climate and vegetation and the conversion of tropical savanna. Geophys Res Lett 29:2052. doi:10. 1029/2002GL015424

Hoffmann WA, Lucatelli VMPC, Silva FJ, Azeuedo INC, Marinho MS, Albuquerque AMS, Lopes AO, Moreira SP (2004) Impact of the invasive alien grass Melinis minutiflora at the savanna-forest ecotone in the Brazilian Cerrado. Divers Distrib 10:99-103

Horowitz C, Martins CR, Walter BMT (2013) Flora exótica no parque nacional de brasília: levantamento e classificação das espécies. Biodivers Bras 3(2):50-73

Huenneke LF, Hamburg SP, Koide R, Mooney HA, Vitousek PM (1990) Effects of soil resources on plant invasion and community structure in Californian serpentine grassland. Ecology 71:478-491

Klink CA (1996) Relação entre o desenvolvimento agrícola e a biodiversidade. In: Pereira RC, Nasser LCB (eds) Anais VIII Simpósio sobre o cerrado, 1st International symposium on tropical savanas - biodiversidade e Produção Sustentável de alimentos e fibras nos cerrados. Embrapa CPAC, Brasília, pp 25-27

Klink CA, Joly CA (1989) Identification and distribution of $\mathrm{C}_{3}$ and $\mathrm{C}_{4}$ grasses in open and shades habitats in São Paulo State Brazil. Biotropica 21:30-34

Kolb A, Alpert P, Enters D, Holzhapfel C (2002) Patterns of invasion within a grassland community. J Ecol 90:871-881

Kraaij J, Ward D (2006) Effects of rain nitrogen fire and grazing on tree recruitment and early survival in bush-encroached savanna South Africa. Plant Ecol 186:235-246

Lambers H, Poorter H (1992) Inherent variation in plant growth: physiological mechanisms and ecological consequences. Adv Ecol Res 23(18):7-261

Lannes LS, Bustamante MMC, Edwards PJ, Venterink HO (2012) Alien and endangered plants in the Brazilian Cerrado exhibit contrasting relationships with vegetation biomass and N: P stoichiometry. New Phytol 196:816-823

Lenza E, Klink CA (2006) Comportamento fenológico de espécies lenhosas em um cerrado sentido restrito de Brasília, DF. Rev Bras Bot 29:627-638

Maciel JR, Oliveira RC, Alves M (2009) Paspalum L (Poaceae: Panicoideae: Paniceae) distribution in the Pernambuco state, Brazil. Acta Bot Bras 23:1145-1161

Mangla S, Sheley RL, James JJ, Radosevich SR (2011) Intra and interspecific competition among invasive and native species during early stages of plant growth. Plant Ecol 212:531-542

Martins CR, Leite LL, Haridasan M (2004) Molasses grass (Melinis minutiflora P. Beauv), aexotic grass species that compromise the recovery of degraded areas in conservation units. Rev Árvore 28:739-747

Masocha MA, Skidmore K, Poshiwa X, Prins HHT (2011) Frequent burning promotes invasions of alien plants into a mesic African savanna. Biol Invasions 13:1641-1648

Matos DMS, Pivello VR (2009) The invasive plant impact on the terrestrial environmentalnatural resources-Some Brazilian cases. Ciênc Cult 61:27-30

Nardoto GB, Bustamante MM, Da C, Pinto AS, Klink CA (2006) Nutrient use efficiency at ecosystem and species level in savanna areas of central Brazil and impacts of fire. J Trop Ecol 22:191-201

Oliveira LC (2004) O gênero Paspalum L., grupo Plicatula (Poaceae: Paniceae), no Brasil. Ph.D. thesis, Biologia Vegetal, Universidade de Campinas, Campinas, 366 pp

Peel MC, Finlayson BL, McMahon TA (2007) Updated world map of the Köppen-Geiger climate classification. Hydrol Earth Syst Sci 11:1633-1644

Pivello VR, Carvalho VMC, Lopes PF, Peccinini AA, Rosso S (1999a) Abundance and distribution of native and alien grasses in a "Cerrado" (Brazilian savanna) biological reserve. Biotropica 31:71-82

Pivello VR, Shida CN, Meirelles ST (1999b) Alien grasses in Brazilian savannas: a threat to the biodiversity. Biodivers Conserv 8:1281-1294

Pivello VR, Oliveras I, Miranda HS, Haridasan M, Sato MN, Meirelles ST (2010) Effect of fires on soil nutrient availability in an open savanna in central Brazil. Plant Soil 337:111-123

Pyšek P, Rihardson DM (2010) Invasive species, environmental change and management, and health. Ann Rev Environ Resour 35:25-55

Pyšek P, Jarošík V, Hulme P, Pergl J, Hejda M, Schaffner U, Vilà M (2012) A global assessment of invasive plant impacts on resident species communities and ecosystems: the interaction of impact measures invading species' traits and environment. Global Change Biol 18:1725-1737

Reatto A, Correia JR, Spera ST, Martins ES (2008) Solo do Bioma Cerrado: aspectos pedológicos. In: Sano SM, Almeida SP, Ribeiro JF (eds) Cerrado: ecologia e flora. Embrapa Cerrados, Brasília, pp 107-149

Rejmánek M (1996) A theory of seed plant invasiveness: the first sketch. Biol Conserv 78:171-181

Richardson DM (2011) Invasion science: The roads travelled and the roads ahead. In: Richardson DM (ed) Fifty years of invasion ecology. The legacy of Charles Elton, WileyBlackwell, Oxford, pp 397-407

Rossiter NA, Setterfield SA, Douglas MM, Hutley LB (2003) Testing the grass-fire cycle: alien grass invasion in the tropical savannas of northern Australia. Divers Distrib 9:169-176

Sankaran M, Ratnam J, Hanan NP (2004) Tree-grass coexistence in savannas revisited-insights from an examination of assumptions and mechanisms invoked in existing models. Ecol Lett 7:480-490

Scholes RJ, Archer SR (1997) Tree-grass interactions in savannas. Annu Rev Ecol Syst 28:517-544

Tilman D (1987) Secondary sucession and the pattern of plant dominance along experimental nitrogen gradients. Ecol Monogr 57:189-214

Tomlinson KW, Sterck FJ, Bongers F, Silva DA, Barbosa ERM, Ward D, Bakker FT, Van Kaauwen M, Prins HT, de Bie S, 
Van Langevelde F (2012) Biomass partitioning and root morphology of savanna trees across a water gradient. J Ecol 100:1113-1121

Tooth IM, Leishman MR (2014) Elevated carbon dioxide and fire reduce biomass of native grass species when grown in competition with invasive exotic grasses in a savanna experimental system. Biol Invasions 16:257-268

Valentim JF, Carneiro JC, Moreira P, Vaz FA (2000) Capimpojuca: uma opção forrageira para os solos de baixa permeabilidade do Acre. Comun Téc Empresa Bras Pesqui Agropecu (Embrapa Acre) 11:1-4

Vallano DM, Selmants PC, Zavaleta ES (2012) Simulated nitrogen deposition enhances the performance of an exotic grass relative to native serpentine grassland competitors. Plant Ecol 213:1015-1026

Vilà M, Weiner J (2004) Are invasive plant species better competitors than native plant species? Evidence from pairwise experiments. Oikos 105:229-238

Vilà M, Espinar JL, Hejda M, Hulme PE, Jarošík V, Maron JL, Pergl J, Sharffner U, Sun Y, Pysek P (2011) Ecological impacts of invasive alien plants: a meta-analysis of their effects on species communities and ecosystems. Ecol Lett 14:702-708

Williams DG, Baruch Z (2000) African grass invasion in the Americas: ecosystem consequences and the role of ecophysiology. Biol Invasions 2:123-140 